\title{
FINANCING OF SCIENCE ADVANCEMENT IN UKRAINE: EXISTENT PROBLEMS AND PROSPECTS OF THEIR SOLUTION
}

\author{
Tetiana BOGOLIB' \\ Pereiaslav-Khmelnytskyi State Pedagogical University named after Hryhorii Skovoroda, Ukraine
}

\begin{abstract}
Science plays an important role of development of national economies of developed countries. Postindustrial society, society of knowledge is a society where scientific discoveries, scientific research results ensure economic growth, economic stability, economic exuberance. In such a society not goods, not movable and real property and not natural resources, including power, put together the main society wealth, but scientific discoveries, new knowledge. Countries, which gain primary income from scientific discoveries and high technologies, are prosperous in the modern world. The purpose of study. A solution of science problems in the modern world should become an important direction of a state's attention to providing national security. Weakening of academic and technological as well as technological potential of the country, research reduction, mass closure of research institutes and centres, several-ford reduction in the volume of funding of science, outflow of specialists and intellectual property abroad for the last three years menace Ukraine with a loss of advanced positions in the world, degradation of knowledge-intensive industries, strengthening of external technological dependence and undermining of its defensive capacity. Such a situation predetermined the topic of our research, its main purpose - identification of problems of science financing and determination of ways to solve them. Research methods. When writing the article, a set of methods and approaches was used that allowed realizing a conceptual unity of the research. Dialectical, system, structural methods are used for the analysis of financing of the science advancement in Ukraine, existent problems of the science financing are generalized with the help of comparative and factorial methods; ways for improving financing of the science advancement are determined by using methods of scientific abstraction, synthesis, functional analysis. The results of the study. In Ukraine, a process of reforming of the public sector of science in conjunction with support of new organizational forms, which correspond to market conditions of economy, is declared. It centre around a reduction in this sector, concentration of resources for supporting restricted number of operating research establishments, accelerated liquidation of research institutes, research centres, scientists' reduction, limitation of financial support. National Academy of Sciences of Ukraine is surviving today; there is no link between science and state, science and business, science and enterprises. Scientists are oriented toward grant schemes, cooperation with foreign research centres. The low level of labour remuneration of scientists, outdated equipment, lack of mechanisms to manage scientific research, managerial functions are performed by those who have never done scientific discoveries. An important is keeping scientific organizations, strengthening of links state - science, business - science, enterprise - science; grant of administrative and financing autonomies to scientific structural departments and bodies, developing the system of national research centres, promotion of technological infrastructure of research organizations through the realization of competitive programs for financing of acquisition of modern scientific equipment, increase in wages of scientists according to the European level. Conclusion and discussion position. A foregrounding of financing of the science advancement of Ukraine is possible through the solution of tasks of integration with scientific and innovative space of the European Union, where the strategy "Europe 2020" and main directions of the Fourth Industrial Revolution are being realized successfully. Ukraine has financial resources for the science advancement, there is required a goodwill of politicians who could make effective the links as state - science, business - science, enterprise - science, as well as commercialize new technological solutions.
\end{abstract}

Key words: financing of science advancement, new technological solutions, scientific research results, integration, scientific equipment, corporate sector of science, research organisms.

JEL Classification: G32, H52, H72

Corresponding author:

${ }^{1}$ Finance-Humanitarian Faculty, Pereiaslav-Khmelnytskyi State Pedagogical University named after Hryhorii Skovoroda.

E-mail: bogolib60@bk.ru 


\section{Introduction}

In modern globalized world, science plays a key role and, in order to build an efficient economy, Ukraine should develop science industry under the influence of high competitiveness, which strengthens in terms of integration processes. It becomes clear that the country's economy would not be able to compete both on internal and external markets if one do not implement scientific discoveries and developments and thus it becomes more efficient and meets new challenges.

Scientific novelty. The purpose of the article is to determine the role andimportance ofscienceforsuccessful economic development of the country, necessity of increase in a volume of scientific developments financing, upgrade of equipment of scientific laboratories, increase in remuneration of labour of scientists.

Actuality of scientific solutions. The world experience shows that building a developed, successful economy, free from export resource dependence, with a high dynamics of economic growth require the economy rebuilding, which will be based on creative technology, introduction of scientific developments into practice, new knowledge creation, learning to use energy efficiency and other advanced technologies. To do this, it is needed not to destroy the science industry, but to increase volumes of financing, invest scientific developments. A realization of the Strategy 2020 in Ukraine completely depends on successful development of science - theory - practice; the basic chain is state business - enterprise - science. Ukrainian scientific system will ensure a stability of the economic growth by means of application of new technological knowledge, the basis of which is financial resources.

The purpose of the research. In Ukraine, over the past three years in dozens of times reduced the financing of science, scientific developments, reduced the number of research institutes and centres, thousands of scientists went abroad, day by day the country destroys its scientific and technological basis, deprives itself of the future. We have proposed ways out of the situation, sources of the science advancement financing.

Methodology of researches. In the research, a set of methods and approaches was used that allowed realizing a conceptual unity of the research. Dialectical, system, structural methods are used for the analysis of financing of the science advancement in Ukraine, existent problems of the science financing are generalized with the help of comparative and factorial methods; ways for improving financing of the science advancement are determined by using methods of scientific abstraction, synthesis, functional analysis.

Scientific results. A consideration of existent approaches and theoretical provisions of financing of the science advancement, analysis of pseudoscientific reforms of science industry allowed grounding a scientific position, according to which the main factors of structural reforms in Ukraine, economic growth, realization of the Strategy "Ukraine 2020" are science, scientific knowledge, scientific discoveries. There are these components, which provide a creation of models of smart development of national economies, economic growth, and national competitiveness. It is possible to develop science, ensure worthy financing by way of four-in-one model: state - business - enterprise science. According to most of economists, in modern terms a global economic development is determined by a combination of two contradictory trends: the world economy dependence on interests of transnational capital, on the one hand, and competition of high tech manufacturing, scientific developments, on the other. A development of new, progressive productions, realization of the Fourth Industrial Revolution are possible only on the basis of scientific research results, intellect, ideas of scientists, but at the same time its basis are financial resources.

Conclusions and discussion position. The financing of the science advancement, creation of new modern scientific centres, rise of scientist, creation of modern facilities and resources of scientific establishments - are the main priorities of Ukrainian society. Sham reforms of scientific sphere are the way towards the feudal system, moving backwards rather than forwards. The situation on the financing of scientific establishments, academic research - are a step forward and a hundred steps backward in the development of the national economy of Ukraine, dead-end road, loss of scientific potential, technological downfall of Ukrainian economy.

\section{Ukrainian science under the structural economic crisis}

A powerful boost of research of science importance for the economic growth of countries was works of $\mathrm{N}$. Kondratev, especially considered by him major cycles of the conjuncture (long waves). There are three types of waves: N. Kondratev's long waves (average duration of 50-60 years), they are concerned with appearance of new sectors and technology; medium waves (7-11 years' periodicity), they related to investment in machines and equipment; short (40 months) waves within the cycle of conjuncture, when new developments are implemented in the manufacturing (Kondratiev, 1993).

There are scientific results of $\mathrm{N}$. Kondratev and J. Schumpeter that served as a peculiar foundation for further evolutionary development of scientific views in the context of cyclical development of economy, which is based on scientific discoveries (Kondratiev, 1993; Schumpeter, 1982).

An important theory of R. Solow who studied a so-called "production function" envisages that economic output depends on labour and capital expenditure, which, according to R. Solow, is based on technological advance (Solow, 1957). 
Famous scientists C.Freeman, C. Perez,J.Millendorfer, G. Dosi have developed the famous technical and economical paradigm, which is based on introduction of scientific discoveries in the manufacturing, further ensuring economic growth (Freeman, 1995; Perez, 2002; Dosi, Freeman and Nelson, 1988). English scientist and public person J. D. Bernal's monumental work Science in History shows a genesis of the theory of technological development, where a link between scientific technological, social innovations at all the stages of society development is revealed. J. Bernal states that the periods of golden age of science coincide with the periods of strengthening of economic activity and technological advance (Bernal, 1956).

Under modern conditions, the world system of economy is increasingly strengthening in the field of new, network-based mode that ensures technological growth.

According to most of economists, in modern terms a global economic development is determined by a combination of two contradictory trends: the world economy dependence on interests of transnational capital, on the one hand, and competition of high tech manufacturing, scientific developments, on the other. On its basis, a rational determination of priorities in the concentration of national resources for learning to use technologies of the fifth technological mode allowed breaking away the peripheral dependence on such countries as Japan, South Korea, China, India, Brazil, learning directions not only of fifth, but also sixth technological mode.

The Fourth Industrial Revolution successfully develops in the modern world. In the world, the Fourth Industrial Revolution is known as scientific revolution and revolution of establishment of post-non-classical scientific type of rationality. Many scientists consider that the Fourth Industrial Revolution has already taken place in the past 30 years of XX century. It occurs due to the appearance of peculiar study subjects, which has led to radical change of science.

In February, 2016 the World Economic Forum in Davos announce that "the Fourth Industrial Revolution" began. Ten trends changing modern society and stipulating the Fourth Industrial Revolution were determined:

1. Development of technologies of customer experience management.

2. Transition from mass production of equal goods to mass customization - mass production of industrial orders.

3. Globalization is replaced by glocalization. This means "Think globally, act locally".

4. Development of the Internet of Things - Internet of items and even Internet of anything.

5. Possibility of remote control of all, including manufacturing.

6. $3 \mathrm{D}$ printing

7. Start-objects, Start-devices, Start-sensors.
8. Production returns home, i.e. development of automation and robot automation bring to naught advantages of cheap labour resources.

9. Keeping to the global standards is becoming the necessity and is required even by local markets.

10. Sustainable development and growth of anything: population, economy, science, technologies on the one hand and stably growing problems of ecology - on the other (Davos-2016: the revolution of the future and the challenges of the present, 2016).

The Fourth Industrial Revolution is connected with new technologies, biotechnologies and artificial intelligence. The World Forum described the Fourth Industrial Revolution as a digital era, as tsunami of technological achievements, which will transform the global economy.

However, Ukraine does not conceive the Fourth Industrial Revolution as an opportunity to use it for overcoming the crisis and progress, ensuring of the economic growth.

Ukraine does not determine the development of science as a priority of development of the national economy of Ukraine.

In the President's Annual Message to the Verkhovna Rada of Ukraine "On the Internal and External Situation of Ukraine" we can find only one sentence about the assimilation of new technology and development of industrial base for modern weapons and importance of timely funding of these programs. The Strategy "Ukraine 2020" absolutely does not stipulate for support of development of science industry. In the Laws of Ukraine "On State Budget of Ukraine" in 20142017 global cuts in expenditures on the development of science can be observed. As a result, there is liquidation of sectoral research institutes, research centres, scientific potential reduction.

\section{Analysis of financing of the science development in Ukraine}

We have analyzed budget expenditures on financing of science and scientific and technical activities in GDP (Table 1).

If analysing the structure of these expenditures, a dominant component of expenditure is used for labour remuneration, payment for energy resources, heat and water services, funds are not allocated at all for upgrading material and technical resources for scientific studies.

In 2015 a new Law of Ukraine "On Science and Scientific and Technical Activity" was adopted, where the provision is made for financing of the science development from the state budget at the level of $1.7 \%$ of GDP, but even in the days of successful economic development of Ukraine this indicator did not exceed $1.06 \%$ of GDP (The law of Ukraine «On scientific and scientific-technical activities $\gg, 2015)$. 
Table 1

Amount of financing of the development of science of Ukraine in 2009-2017

\begin{tabular}{|l|c|c|c|c|c|c|c|c|c|}
\hline \multicolumn{1}{|c|}{ Indicators } & 2009 & 2010 & 2011 & 2012 & 2013 & 2014 & 2015 & 2016 & 2017 \\
\hline $\begin{array}{l}\text { Financing of science and scientific } \\
\text { and technical activities }\end{array}$ & 0,86 & 0,83 & 0,73 & 0,70 & 0,77 & 0,66 & 0,62 & 0,45 & 0,53 \\
\hline $\begin{array}{l}\text { Funds of the State Budget and local } \\
\text { budgets }\end{array}$ & 0,37 & 0,34 & 0,29 & 0,27 & 0,33 & 0,26 & 0,22 & 0,18 & 0,20 \\
\hline
\end{tabular}

* Source: data of the State Statistics Service of Ukraine (Scientific and innovative activity in Ukraine in 2015, 2016)

In 2016, 5.3 billion hryvnia were allocated for the development of science and distributed among 25 administrators of monetary funds, mainly to the Ministry of Education and Science of Ukraine and National Academy of Sciences of Ukraine. More than 185 billion hryvnias were allocated among different ministries and departments for paying applied and fundamental research and scientific inquiries. The money goes nowhere and influences on cuts in public expenditure on science.

In Ukraine, the ratio of scientific and technological works in GDP in 200-2017 is constantly reducing. In 200 the share of scientific and technological works in GDP amounted to $1.2 \%$, in 2014 it became twice as little - $0.66 \%$, in 2015 amounted to $0.33 \%, 2016-0.26 \%$, and in 2017 it will amount to $0.22 \%$. These indicators are not significant in comparison with the OECD countries and their further reduction will negatively affect the country's economic development. As a comparison, average gross expenditures for scientific and technological works in the OECD countries in 2013 amounted to $2.36 \%$ of GDP, in the EU countries - $1.91 \%$ of GDP, and in 2016 in the OECD countries they amounted to $2.7 \%$, and in the EU countries $-2.2 \%$ of GDP (herewith it is necessary to take into account inequivalence of volumes of GDP) (Key figures for the 2006-2016 financial condition (the first half) years, 2016).

In Ukraine, about a half of expenses for scientific works and development works are financed by the state, up to $30 \%$ - by private sector and more than $15 \%$ - by foreign sources. The ratio of public funds plays the main role in the distribution of financing of scientific and technological works by sources where the money comes from in Ukraine, whereas business sector occupies the second place.

As a comparison, according to data of Eurostat, as an average in the EU countries in 2016 business financed more than half $(57.6 \%)$ of expenses for scientific and technological works, $32.8 \%$ - state, and 9.4\% - financial sources of other states. In developed countries the ratio of expenses for scientific and technological works from the side of business is higher. For example, in Japan (2015) - 78.6\%, in China - 76.2\% (2015), in the USA (2014) -61.7\% (Key figures for the 2006-2016 financial condition (the first half) years, 2016).

In 2017 provisions in the State Budget for the National Academy of Sciences of Ukraine are made in the amount of 2943583.2 thousand hryvnias (2.9 billion hryvnias), by general fund - 2270302.7 thousand hryvnias ( 2.2 billion hryvnias), by special fund -673280.5 thousand hryvnias. An inclusion of finances of the special fund into expenditures of the State Budget was not in compliance with the existent world practice and artificially increases budget expenses for science (The law of Ukraine «On state budget of Ukraine for 2017», 2017).

Expenses of the Presidium of the National Academy of Sciences of Ukraine are described in the amount of 73591.4 thousand hryvnias, expenses on the budgetary program "Fundamental and Applied Scientific Researches" are 2821284.8 thousand hryvnias. Expenses for the activities of the National Academy of Educational Sciences of Ukraine will amount to 160123.3 thousand hryvnias according to the Program "Fundamental and Applied Scientific Researches" - 110416.9 thousand hryvnias. Expenses for the activities of the National Academy of Medical Sciences of Ukraine will be 480760.7 thousand hryvnias (The law of Ukraine $\ll$ On state budget of Ukraine for 2017», 2017). According to the Program "Fundamental and Applied Scientific Researches" - 196950.6 thousand hryvnias (The law of Ukraine «On state budget of Ukraine for 2017», 2017). According to the program "Diagnosis and Treatment of Diseases" - 235600.7 thousand hryvnias.

National Academy of Arts of Ukraine will have expenses to the value of 18261.2 thousand hryvnias, according to the budgetary program "Fundamental Research and Training of Scientific Personnel in the Field of Arts" - 7708.1 thousand hryvnias.

National Academy of Legal Sciences of Ukraine will have expenses to the value of 31845.4 thousand hryvnias, according to the budgetary program "Scientific and Organizational Activity of the Presidia of the National Academy of Legal Sciences of Ukraine" - 10481.0 thousand hryvnias, according to the budgetary program "Fundamental Studies, Applied Scientific Researches" 21364.4 thousand hryvnias.

National Academy of Agrarian Sciences of Ukraine will be financed to the value of 682284.5 thousand hryvnias, according to the budgetary program "Scientific and Organizational Activity of the Presidia of the National Academy of Agrarian Sciences of Ukraine" 22627.4 thousand hryvnias, according to the budgetary program "Fundamental Studies, Applied Scientific Researches" - 642998.3 (The law of Ukraine « On state budget of Ukraine for 2017», 2017). 
For activities concerning the support of scientific and research establishments - 1527.5 thousand hryvnias, according to the budgetary program "Preservation of the Nature Reserve Fund in the Askania-Nova Biosphere Reserve" - 15131.3 thousand hryvnias (The law of Ukraine «On state budget of Ukraine for 2017», 2017).

Ministry of Education and Science of Ukraine will be funded by the budgetary program "Fulfilment of Obligations of Ukraine in the Field of International Cooperation in the Areas of Science and Technology" - 39312.5 thousand hryvnias, according to the budgetary program "Researches at Vernadsky Research Base" - 58303.6 thousand hryvnias, according to the budgetary program "Horizon 2020" 312214.4 thousand hryvnias (The law of Ukraine «On state budget of Ukraine for 2017», 2017).

All expenditures include funds of general and special funds, which essentially increase volumes of financing.

The analysis has shown that the volumes of the science financing in the period of 2010-2017 decreased by $0.8 \%$ of GDP, which will lead to the shutdown of about 25 scientific institutes and centres and laying off about $30 \%$ of scientific personnel, say nothing of low wages, at the level of doctor of sciences, professor - 5400 hryvnias (200 US dollars), which provides Ukraine the 146th place in the world by the level of scientific personnel labour remuneration.

\section{Survival of Ukrainian science}

In 2016, the budget for development of science was reduced by $20 \%$, in 2017 a reduction will amount to $25 \%$. Underfunding of Ukrainian science can be shortly explained: "Country without science - country without future”. Many Ukrainian scientists are forced to apply for foreign grants. It is prestigious, fashionably. But, what it gives to Ukrainian economy? Nothing. All the scientific research results, scholarly results belong to grantors, Ukraine even cannot sell this research result, research finding. If the state be a customer of research and development projects, they will help to modernize Ukrainian economy, provide overcoming of crisis.

In 2017 it is planned to lay off each third scientist of SRI. Who will be laid off is also the relevant question here. There is no need in smart people and thus intellectual potential is the first that will be reduced. In these conditions, the lack of knowledge, inactivity, and farm mentality overruled common sense.

In Ukraine, the Program "Horizon 2020" is obstinately advertised - it is the biggest EU research programme, its budget is about 80 billion euro, it is designed for 20142020. Ukrainian scientists filled about 400 applications, 40 applications went through. It is not over the bad projects, but poor financing, for 2017 in Ukraine it amounts to 312214.4 thousand hryvnias (Scientific and innovative activity in Ukraine in 2015, 2016).

A real necessity is caused by the underrun of the National Academy as a developer of fundamental scientific problems. NAS of Ukraine conducts research by scientific priorities and they must be kept, not destroyed. An important direction should be working-out of programs of institutional development of the academy of sciences aimed at providing use of potential of fundamental and applied science for the purposes of modernization of systems of education, health care, agricultural development. At the same time, there must be ensured the closest integration of institutes of the national academies with corresponding higher educational establishments, activated cooperation with foreign scientific centres and interested organizations that operate in the field of education, medicine and agriculture.

The state should develop a program of integration of academic institutes with leading universities of the regions of Ukraine in the part of providing heredity of scientific schools, first of all, at the expense of introduction of multi-level system of stimulation of the young people attraction to the field of science and fastening in this sphere (demonstration of advantages of scientific creativity; ensuring of targeted funding of researches and developments of young scientists; promotion of achievements of the young scientists).

An influence of academic science on the acceleration of a process formation takes place at providing and through an understanding by government authorities of all levels that the establishment of operating NIS, where the science occupies the central place and where is realized a strategic discoveries, is a strategic map on the way of Ukraine to the civilised world. A strategic task in the aspect of science development is a return of our country to the number of leading world scientific states able to make groundbreaking fundamental and applied researches on relevant for the world economy and science as well as industrial for Ukraine directions.

There is necessary further concentration of resources on priority directions and formation of a network of scientific research centres, research universities and centres of advantages that have a global competitiveness and are provided with material and technical as well as informational resources for conducting investigations at the level of the best world centres in the corresponding area.

All this will allow Ukrainian science to survive in the situation as it has developed.

\section{Corporate science}

The improvement of cooperation of academic science and business should be based on the creation of conditions for overcoming a closed nature of development of scientific research institutes and other establishments of science on the basis of integration within the strategy of structural-scientific transformations of the science development, innovative technological sector of industry and entrepreneurship by means of realization of a complex of mutually 
agreed institutional factors, first of all, formation of corresponding innovative technological development due to effective support of the state; determination and substantiation of favourable conditions of effective mechanism concerning the stimulation of commercialization of research and development in the science sector, creation of mechanisms of transferring a scientific product into production.

The state should not shorten, but develop the network of national research centres (NRC) in the fields of technology advances of the world level, which are preserved (aircraft engineering, new materials, biotechnology), and providing in their framework of a full technological cycle from research to commercialization. Among other things, it requires a support of development of technological infrastructure of research organizations through the realization of competitive programme of financing of their bought modern scientific equipment, access to which will be provided for interested organizations within the organization of common use centres.

The necessity to increase the ratio of non-governmental sources of financing of research and development works is specified not only and not so much by tasks of budget savings as by unwillingness to make science the basis for economic development, thus it is necessary to a greater extent to build more strong and flexible orientation of the science development, first of all, applied for economic development. A growth of the ratio of private sector in the field of science should take place due to this segment's growth rates.

A target of changes in this direction can be an increase of the ration of private sector to 2020 to the level medium for the countries of OECD. The solution of this task envisages using various levellers and instruments existing in the state. In order to extend private sector to 2020, generation of knowledge and stimulation of higher-thananticipated growth of financing, fundamental and applied researches from private sources should be legislated in terms of access right of scientific and educational forms of ownership, which have necessary qualification, to all kinds of public finance of fundamental and applied researches that will be carried out on a competitive basis. At the same time, the ratio of competitive financing of researches in general volume of budgetary funds allocated to support science should be gradually increased.

One of the most important directions is the development of a corporate science upon condition of further development: use of the main stockholder in the largest state companies and companies with prevalence of the state for increasing in the medium term of volume of expenses for financing $R \& D$ to the level peculiar to the companies of corresponding sectors of economy and range of activity in the countries of OECD, including promotion of internal development of corporate science and scientific research organizations within the largest companies; growth of co-financing of applied R\&D and developmental works, which are performed by enterprises through subsidies, including within the framework of state target programs, programs of support for small and medium-sized business, as well as programs of co-financing of enterprises' expenses on applied research, the main executors are universities; providing access of interested enterprises and organizations to the performance of infrastructure of centres of technology transfer, centres of common use of scientific equipment and extreme installation, and also using equipment of other state scientific and educational organizations on a commercial basis. Among important events in this context - support for development of business plans of commercialization of new technologies for creating a favourable investment climate, target informing of potential investors concerning perspective $R \& D$ and developmental works created by scientific establishments.

\section{Conclusion}

The research has shown that in Ukraine there is a policy aimed at destroying scientific establishments, scientific centres; the state for the period of 2014-2017 is reducing budget financing of science, and business plays not an important role in financing of the science development. in 2016, the volumes of financing of science decreased by $20 \%$, in 2017 the decrease is planned at the amount of $25 \%$, this leads to the shutdown of scientific institutes, scientific centres, laying off scientific personnel. The labour remuneration of scientists is absolutely brought to nothing. The chain state - business - enterprise science is broken. Science is not the basis for economic development of the state. The declared form of scientific institutions has led to their destroying. This situation can be characterized as a step forward - a hundred steps backward. The step forward - is the adoption of progressive Law of Ukraine "On Science and Scientific and Technical Activity" (Scientific and innovative activity in Ukraine in 2015, 2016), which does not come into force. An orientation toward foreign grants is a rejection of scientific discoveries and of a possibility to make them to serve the national economy of Ukraine.

The state should determine science as a priority of development, develop a corresponding strategy, which will be based on main provisions of the Strategy "Europe 2020" and the Fourth Industrial Revolution. Ukraine must use is chance of technological breakthrough.

The economy modernization on the basis of domestic technologies requires a significant growth of investment in science - only for the development of technologies it is necessary to invest in the science development at least $5 \%$ of GDP during five years.

A concentration of resources within the framework of determination of the list of critical technologies of Ukraine and priorities of scientific and technological development is needed that will ensure an implementation of competitive advantages of Ukrainian sector of research activities in the world market. 


\section{References:}

Bogolib, T.M. (2014). Commercialization of scientific developments of universities. Economy of Ukraine, No. 4, pp. 33-51.

Davos-2016: the revolution of the future and the challenges of the present (2016). Retrieved from: http:/ ru.evronews.com/2016/01/19/what-is-the-4th-industri-al-revolution.

Europe 2020. Smart growth (2016). Retrieved from: http://rpp.nashaucheba.ru/does/index-44576.

Key figures for the 2006-2016 financial condition (the first half) years (2016). Retrieved from: http:/minfin.gov. ua/control/uk/publish.

The new European strategy «Europe 2020» (2016). Retrieved from: http://eulaw.ru/content/.

The law of Ukraine «On state budget of Ukraine for 2017» (2017). Kyiv: the Verkhovna Rada, 132 p.

The law of Ukraine «On state budget of Ukraine for 2016» (2016). Kyiv: Parliament, $124 \mathrm{p}$.

Kondratiev, N.D. (1993). Dissenting opinion. Book 1, 2. Moscow, 284 p.

Schumpeter, J.A. (1982). The theory of economic development (Study of business profits, capital, credit, interest and cycle conditions). Moscow: Progress, $356 \mathrm{p}$.

Solow, R. (1957). Technical change and the aggregate production function. Review of Economics and statistics, pp. 312-320.

Freeman, C. (1995). The National system of innovation in Historical Perspective. Cambridge journal of Economics, Vol. 19, No 1.

Perez, C. (2002). Technological revolutions and Financial Capital. The Dynamics of Bues and Golden Ages, Ed. Elgar Pbl., 402 p.

Bernal, D. (1956). Science in history. Moscow: Izd-vo Inostr. lit., 735 p.

Dosi, G., Freeman, C. and Nelson, R. (1988). Technical Change and Economic Theory, London: Pinter Publichers, $316 \mathrm{p}$.

Scientific and innovative activity in Ukraine in 2015 (2016). Kyiv: state statistics Committee, 316 p.

The law of Ukraine «On scientific and scientific-technical activities» (2015). Kyiv: The Verkhovna Rada, 42 p.

\section{Татьяна БОГОЛИБ}

ФИНАНСИРОВАНИЕ РАЗВИТИЯ НАУКИ В УКРАИНЕ: СУЩЕСТВУЮЩИЕ ПРОБЛЕМЫ И ПЕРСПЕКТИВЫ ИХ РЕШЕНИЯ

Аннотация. Наука играет важную роль развития национальных экономик развитых стран. Постиндустриальное общество, общество знаний является обществом, в котором научные открытия, научные разработки обеспечивают экономический рост, экономическую стабильность, экономическое процветание. В таком обществе не вещи, не движимое и недвижимое имущество и не природные, в том числе энергетические, ресурсы составляют главные богатства общества, а научные открытия, новые знания. Страны, которые получают основные доходы от научных открытий и высоких технологий процветают в современном мире. Цель исследования. Решение проблем науки в современном мире должно стать важным направлением внимания государства к обеспечению национальной безопасности. Ослабление научно-технологического и технологического потенциала страны, сокращение исследований, массовое закрытие научно-исследовательских институтов и центров, сокращение в разы объемов финансирования науки, отток за рубеж специалистов и интеллектуальной собственности за последние три года угрожают Украине потерей передовых позиций в мире, деградацией наукоемких производств, усилением внешней технологической зависимости и подрывом ее обороноспособности. Такое положение и определило тему нашего исследования, его главную цель - определение проблем финансового обеспечения науки и определение путей их решения. Методы исследования. При написании статьи использовано совокупность методов и подходов, что позволило реализовать концептуальное единство исследования. Диалектический, системный, структурный методы использованы при анализе финансирования развития науки в Украине, при помощи сравнительного и факторного методов обобщены существующие проблемы финансирования науки; при помощи методов научной абстракции, синтеза, функционального анализа определены пути улучшения финансирования развития науки. Результаты исследования. В Украине задекларировано процесс осуществления реформы государственного сектора науки в соединении с поддержкой новых организационных форм, которые соответствуют рыночным условиям хозяйствования. Ее содержание заключается в сокращении этой отрасли, концентрации ресурсов на поддержку ограниченного количества действенных научно-исследовательских организаций, ускоренной ликвидации научных институтов, научных центров, сокращении ученых, ограничении финансового обеспечения. Национальная академия наук 
Vol. 2, No. 5, 2016

Украины сегодня выживает, отсутствует связь науки и государства, науки и бизнеса, науки и предприятий. Ученых ориентируют на грантовые программы, сотрудничество из зарубежными научными центрами. Низкий уровень оплаты труда ученых, устаревшие оборудования, отсутствие механизмов управления научными исследованиями, управленческие функции исполняют те, кто никогда не делал научных открытий. Важным является сохранение научных организаций, укрепление звеньев государство - наука, бизнес - наука, предприятие - наука; предоставление административной и финансовой автономии научным структурным подразделениям и коллективам, развитие системы национальных исследовательских центров, поддержка развития технологической инфраструктуры исследовательских организаций через реализацию конкурсных программ финансирования приобретения современного научного оборудования, увеличение заработных плат ученых до уровня европейских. Выводы. Актуализация процессов финансирования развития науки Украины возможна через решение задач интеграции с научным и инновационным пространством Европейского Союза, где успешно реализуется стратегия «Европа 2020» и основные направления 4 Индустриальной революции. В Украине есть финансовые ресурсы для развития науки, нужна добрая воля политиков, которые могли бы сделать действенными цепи государство - наука, бизнес - наука, предприятие наука, а также осуществлять коммерциализацию новых технологических решений. 